\title{
A New Rhodamine B Derivative As a Colorimetric Chemosensor for Recognition of Copper(II) Ion
}

\author{
Lijun Tang, ${ }^{*}$ Fangfang Li, Minghui Liu, and Raju Nandhakumar ${ }^{\dagger, *}$ \\ College of Chemistry and Chemical Engineering, Liaoning Key Laboratory for the Synthesis and Application of Functional \\ Compounds, Bohai University, Jinzhou 121013, P. R. China.*E-mail: lijuntang@tom.com \\ ${ }^{\dagger}$ Department of Chemistry, Karunya University, Karunya Nagar, Coimbatore - 641114. TamilNadu, India \\ *E-mail: rajunandhakumar@yahoo.com \\ Received August 28, 2010, Accepted September 7, 2010
}

\begin{abstract}
A new rhodamine-based sensor 1 was designed and synthesized by incorporating rhodamine $\mathrm{B}$ and benzimidazole moieties. Sensor 1 exhibits high selectivity and sensitivity to $\mathrm{Cu}^{2+}$ in $\mathrm{CH}_{3} \mathrm{CN}$-water solution (HEPES buffer, $\mathrm{pH}=7.0$ ) with an obvious color change from colorless to pink. Other metal ions such as $\mathrm{Hg}^{2+}, \mathrm{Ag}^{+}, \mathrm{Pb}^{2+}, \mathrm{Sr}^{2+}, \mathrm{Ba}^{2+}, \mathrm{Cd}^{2+}, \mathrm{Ni}^{2+}, \mathrm{Co}^{2+}$, $\mathrm{Fe}^{2+}, \mathrm{Mn}^{2+}, \mathrm{Cu}^{2+}, \mathrm{Zn}^{2+}, \mathrm{Ce}^{3+}, \mathrm{Mg}^{2+}, \mathrm{K}^{+}$and $\mathrm{Na}^{+}$had no such color change and have no significant influence on $\mathrm{Cu}^{2+} \mathrm{re}^{-}$ cognition process. The interaction of $\mathrm{Cu}^{2+}$ and sensor 1 was proven to adopt a 1:1 binding stoichiometry and the recognition process is reversible.
\end{abstract}

Key Words: Colorimetric, Chemosensor, Rhodamine B, Copper recognition

\section{Introduction}

Copper being an essential trace element for plants and animals, is the third most abundant transition metal following zinc and iron in human bodies. ${ }^{1}$ It plays a crucial role in many fundamental physiological processes in organisms. For instance, it serves as a catalytic cofactor for a variety of metalloenzymes, including superoxide dismutase, cytochrome c oxidase and tyrosinase. ${ }^{2}$ Whereas, under overloading conditions, copper exhibits toxicity associated with neurodegenerative diseases such as Alzheimer's disease and prion diseases. ${ }^{3}$ In addition, it has been suspected to cause infant liver damage in recent years. ${ }^{4}$ Due to its janus-faced properties of copper ion in organisms, considerable attention has been devoted to the design of efficient and selective colorimetric chemosensors for $\mathrm{Cu}^{2+}$ because of its simplicity, quick and nondestructive advantages of the absorption method.

Rhodamines are an important class of fluorogenic and chromogenic probes, which are the ideal platforms for development of colorimetric chemosensors for specific heavy and transition metal ions. They have excellent spectroscopic properties such as long-wavelength emission, high fluorescence quantum yield, and large molar extinction coefficient. Recently, utilization of rhodamine spirolactam ring-opening process for the detection of metal ions have been well documented. ${ }^{6}$ The spirolactam form is basically colorless, while the metal induced ring-opened amide form gives rise to strong absorption within the visible range, ${ }^{7}$ this feature provides a vital path way for colorimetric detection of metal ions.

Herein, we designed a new benzimidazole containing rhodamine $\mathrm{B}$ derivative, chemosensor $\mathbf{1}$, for colorimetric recognition of $\mathrm{Cu}^{2+}$. It is well-known that benzimidazole moiety has been widely applied as copper binding ligands due to its high affinity toward $\mathrm{Cu}^{2+}$. Therefore, we speculated that by incorporating the 2-aminobenzimidazole moiety into a rhodamine-based probe would (1) increase the affinity and selectivity to $\mathrm{Cu}^{2+}$ in

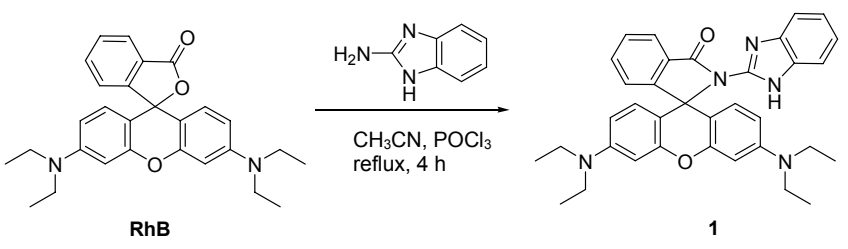

Scheme 1. Synthesis of chemosensor 1

competitive aqueous media, (2) realize real-time detection of $\mathrm{Cu}^{2+}$ through colorimetric response, and (3) recognize $\mathrm{Cu}^{2+}$ reversibly.

\section{Experimental Section}

General methods and materials. ${ }^{1} \mathrm{H}$ NMR spectra and ${ }^{13} \mathrm{C}$ NMR spectra were obtained on a Varian INOVA-400 MHz and Bruker AV-300 MHz Spectrometer, respectively. Chemical shifts were expressed in ppm and tetramethylsilane (TMS) was used as internal standard. High-resolution mass spectrometry (HRMS) was carried out on a UPLC/Q Tof mass spectrometer. UV spectra were measured on a SP-1900 spectrophotometer at room temperature. Chemical reagents for synthesis obtained commercially were used without further purification.

Synthesis of sensor 1. To a stirred mixture of rhodamine B $(2.0 \mathrm{~g}, 4.52 \mathrm{mmol})$ and 2-aminobenzimidazole ( $0.72 \mathrm{~g}, 5.43$ $\mathrm{mmol}$ ) in $30 \mathrm{~mL}$ of anhydrous acetonitrile was added a few drops of phosphorus oxychloride at room temperature, and heated to reflux for $4 \mathrm{~h}$. After cooled to room temperature, the resulting solution was poured into $200 \mathrm{~mL}$ of cold water, and extracted with dichloromethane. The organic layer was then washed with aqueous $\mathrm{NaOH}$ solution and dried over anhydrous $\mathrm{Na}_{2} \mathrm{SO}_{4}$. Then the solvent was evaporated under reduced pressure and the residue was purified by silica gel column chromatography with ethyl acetate-methanol $(10: 1, \mathrm{v} / \mathrm{v})$ as eluent to give sensor 1. Yield: $1.56 \mathrm{~g}(62 \%)$, white solid, mp. $156-157^{\circ} \mathrm{C}$. ${ }^{1} \mathrm{H}$ NMR 
$\left(400 \mathrm{MHz}, \mathrm{CDCl}_{3}\right) \delta 11.16(\mathrm{~s}, 1 \mathrm{H}), 8.04(\mathrm{~d}, 1 \mathrm{H}, J=8.0 \mathrm{~Hz})$, 7.60-7.52 (m, 2H), $7.44(\mathrm{~s}, 1 \mathrm{H}), 7.30(\mathrm{~s}, 1 \mathrm{H}), 7.21(\mathrm{~d}, 1 \mathrm{H}, J=8.0$ $\mathrm{Hz})$, 7.07-7.03 (m, 2H), $6.48(\mathrm{~s}, 2 \mathrm{H}), 6.41(\mathrm{~d}, 2 \mathrm{H}, J=8.0 \mathrm{~Hz})$, $6.14(\mathrm{~d}, 2 \mathrm{H}, J=8.0 \mathrm{~Hz}), 3.30(\mathrm{q}, 8 \mathrm{H}, J=8.0 \mathrm{~Hz}), 1.14(\mathrm{t}, 12 \mathrm{H}$, $J=8.0 \mathrm{~Hz}) ;{ }^{13} \mathrm{C} \mathrm{NMR}\left(75 \mathrm{MHz}, \mathrm{CDCl}_{3}\right) \delta 153.8,148.6,134.3$, 131.4, 128.5, 127.7, 124.7, 123.3, 121.3, 121.2, 119.1, 109.9, 107.2, 106.3, 97.7, 44.2, 12.6; HRMS-ESI $[1+\mathrm{H}]^{+}$cald. $\mathrm{m} / \mathrm{z}$ (558.2869), found $\mathrm{m} / \mathrm{z}(558.2885)$.

\section{Results and Discussion}

Chemosensor 1 was readily prepared by a one-step condensation of rhodamine B and 2-aminobenzimidazole in anhydrous acetonitrile in the presence of a catalytic amount of phosphorus oxychloride. ${ }^{9}$ The structure of 1 was confirmed by NMR and high resolution mass spectroscopy, and the results are in good agreement with the structure presented.

Our preliminary absorption spectra studies showed that sensor 1 has a good selectivity to $\mathrm{Cu}^{2+}$ in $\mathrm{CH}_{3} \mathrm{CN}$-water $(2: 3, \mathrm{v} / \mathrm{v}$, HEPES $10 \mathrm{mM}, \mathrm{pH}=7.0$ ) solution. Solution of sensor 1 is colorless and has no absorption in the visible range. Upon addition of $\mathrm{Cu}^{2+}$, the color changes to pink and a new absorption band centered at $557 \mathrm{~nm}$ was formed. We then investigated the time evolution of the responses of $1(10 \mu \mathrm{M})$ in the presence of 20 equiv of $\mathrm{Cu}^{2+}$ in $\mathrm{CH}_{3} \mathrm{CN}$-water (2:3, v/v, HEPES $10 \mathrm{mM}, \mathrm{pH}=$ 7.0) because a short time response is necessary for a chemosensor to monitor metal ions in aqueous media. As shown in Figure 1, upon addition of 20 equiv of $\mathrm{Cu}^{2+}$ to 1 solution, the absorption intensity at $557 \mathrm{~nm}$ of the tested solution reaches maximum in 2 min and does not change with more reaction time, which indicates that the interaction of $\mathbf{1}$ and $\mathrm{Cu}^{2+}$ was completed in 2 min. Hence, 1 is a sensitive $\mathrm{Cu}^{2+}$ sensor and could be applied in real-time detection of $\mathrm{Cu}^{2+}$ in environmental analysis. Therefore all the absorption spectral data in this work are recorded at $2 \mathrm{~min}$ after the addition of ionic species.

The sensing property of $\mathbf{1}$ toward $\mathrm{Cu}^{2+}$ was then investigated by incremental addition of $\mathrm{Cu}^{2+}$ to $\mathbf{1}$ solution. As shown in Figure 2, upon addition of $\mathrm{Cu}^{2+}$ ( 0 to 8.0 equiv), the new absorption band centered at $557 \mathrm{~nm}$ increased gradually, which cor-

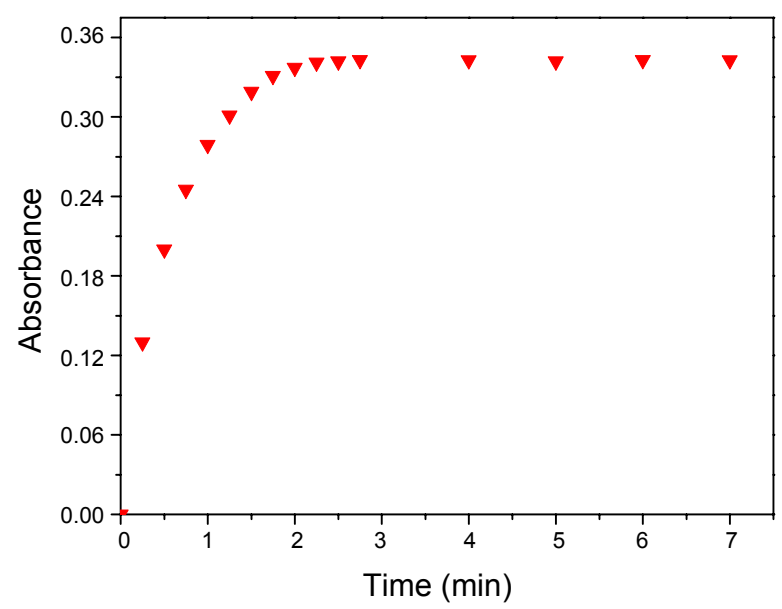

Figure 1. Changes of absorption intensity of 1 at $557 \mathrm{~nm}$ in the presence of 20 equiv of $\mathrm{Cu}^{2+}$ as a function of time $(0.0$ to $7.0 \mathrm{~min})$. responds to the ring-opening process of the spirolactam form of 1. Linear fitting of the titration profiles using Benesi-Hildebrand plot based on a 1:1 binding mode results in a good linearity (correlation coefficient is over 0.99) (Fig. 3), which strongly support the 1:1 binding stoichiometry of $\mathbf{1}$ and $\mathrm{Cu}^{2+}$, and the binding constant is found to be $4.27 \times 10^{5} \mathrm{M}^{-1}$.

The 1:1 binding stoichiometry of $\mathrm{Cu}^{2+}$ and $\mathbf{1}$ was further proved by Job's plot according to the continuous variations with a total concentration of $\left[\mathrm{Cu}^{2+}\right]+[1]$ as $5.0 \times 10^{-5} \mathrm{M}$. (Fig. 4). The absorbance exhibited a maximum when the molar fraction of $\mathrm{Cu}^{2+}$ was 0.5 , which also demonstrates the $1: 1$ binding stoichiometry is adopted between $\mathbf{1}$ and $\mathrm{Cu}^{2+}$.

To further validate the selectivity of $\mathbf{1}$ to $\mathrm{Cu}^{2+}$ over other metal ions, the absorption response of $1(10 \mu \mathrm{M})$ toward various metal ions was conducted by $\mathrm{UV}$-vis absorption in $\mathrm{CH}_{3} \mathrm{CN}$-water $(2: 3, \mathrm{v} / \mathrm{v}$, HEPES $10 \mathrm{mM}, \mathrm{pH}=7.0)$ solution and the results are shown in Figure 5. The free sensor 1 remained colorless and did not exhibit apparent absorption above $450 \mathrm{~nm}$ in the aforementioned buffer solution. Upon addition of 8.0 equiv of $\mathrm{Cu}^{2+}$ into the colorless solution of $\mathbf{1}$, a new strong absorption band

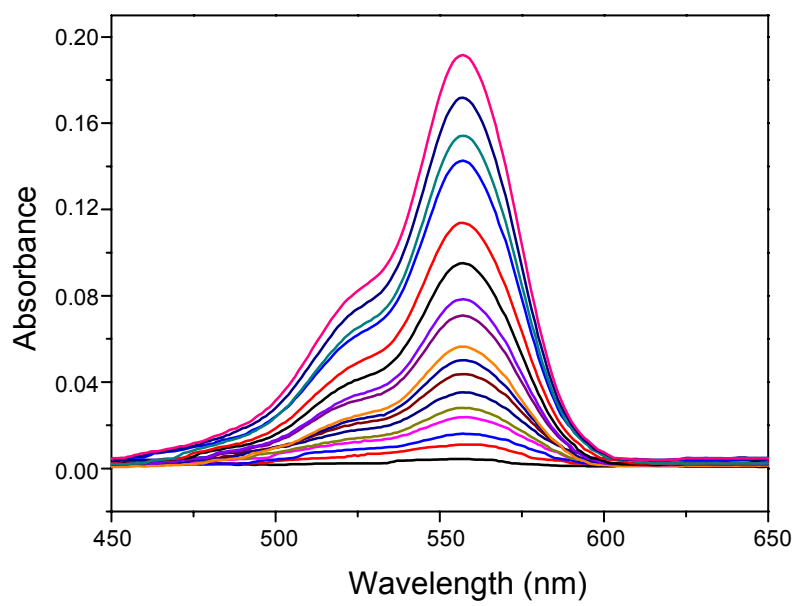

Figure 2. Changes in absorption spectra of $1\left(1.0 \times 10^{-5} \mathrm{M}\right)$ measured in $\mathrm{CH}_{3} \mathrm{CN}-\mathrm{H}_{2} \mathrm{O}(2: 3, \mathrm{v} / \mathrm{v}$, HEPES $10 \mathrm{mM}, \mathrm{pH}=7.0)$ upon addition of $\mathrm{Cu}^{2+}$ (0 to 8.0 equiv).

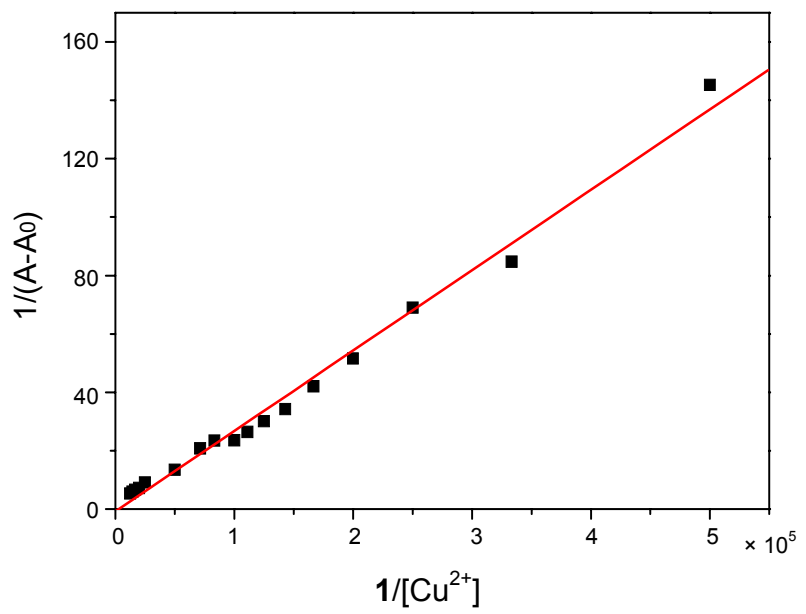

Figure 3. Benesi-Hildebrand plot (absorbance at $557 \mathrm{~nm}$ ) of $\mathbf{1}$ using 1:1 stoichiometry for association between 1 and $\mathrm{Cu}^{2+}$. 


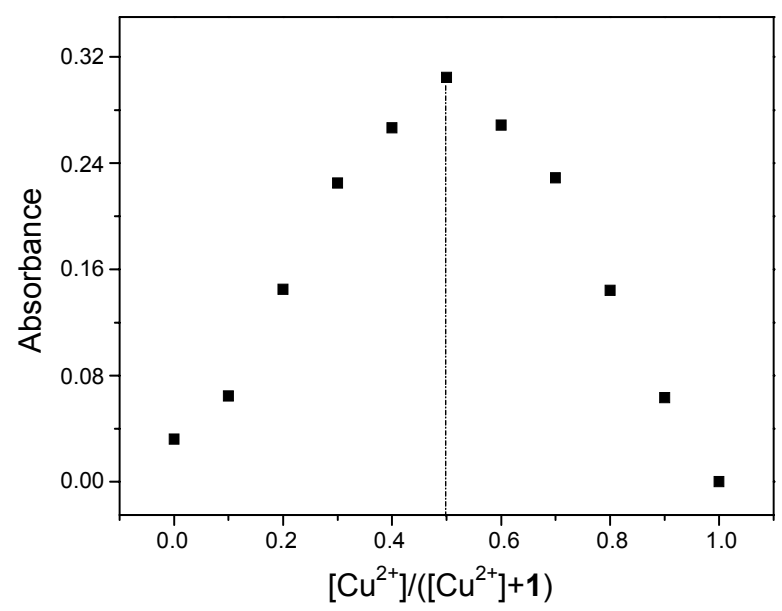

Figure 4. Job' plot monitored at $557 \mathrm{~nm}$, the total concentration of $\left[\mathrm{Cu}^{2+}\right]+[1]$ was $5.0 \times 10^{-5} \mathrm{M}$.

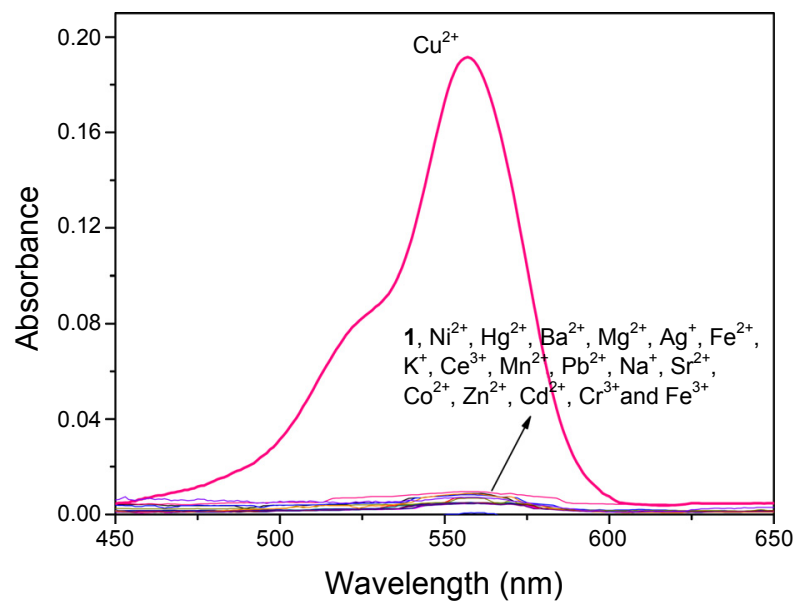

Figure 5. The absorption spectra of $1\left(1.0 \times 10^{-5} \mathrm{M}\right)$ upon addition of various metal ions.

centered at $557 \mathrm{~nm}$ was formed accompanied with a color change from colorless to pink. Whereas, other metal ions such as $\mathrm{Hg}^{2+}, \mathrm{Ag}^{+}, \mathrm{Pb}^{2+}, \mathrm{Sr}^{2+}, \mathrm{Ba}^{2+}, \mathrm{Cd}^{2+}, \mathrm{Ni}^{2+}, \mathrm{Co}^{2+}, \mathrm{Fe}^{2+}, \mathrm{Mn}^{2+}, \mathrm{Cu}^{2+}$, $\mathrm{Zn}^{2+}, \mathrm{Ce}^{3+}, \mathrm{Cr}^{3+}, \mathrm{Mg}^{2+}, \mathrm{K}^{+}$and $\mathrm{Na}^{+}$(8.0 equiv of each) did not induce significant absorption changes under the identical conditions. These results indicate that sensor $\mathbf{1}$ has a remarkable selectivity towards $\mathrm{Cu}^{2+}$.

Achieving high selectivity for the analyte of interest over a complex background of potentially competitive species is an important feature for an effective sensor. Hence, the competition experiments in the presence of potentially competitive metal ions were carried out and the results are depicted in Figure 6. Except $\mathrm{Cu}^{2+}$, other metal ions (8.0 equiv to 1 ) do not produce significant absorption changes. Nevertheless, upon addition of $\mathrm{Cu}^{2+}$ (8.0 equiv to $\left.\mathbf{1}\right)$ to the solution containing $\mathbf{1}$ and other metal ion, a drastic increase in absorption at $557 \mathrm{~nm}$ was observed. From these results, it is inferred that the recognition of $\mathrm{Cu}^{2+}$ by $\mathbf{1}$ is not significantly influenced by other coexisting metal ions and therefore 1 exhibits a very high selectivity toward $\mathrm{Cu}^{2+}$.

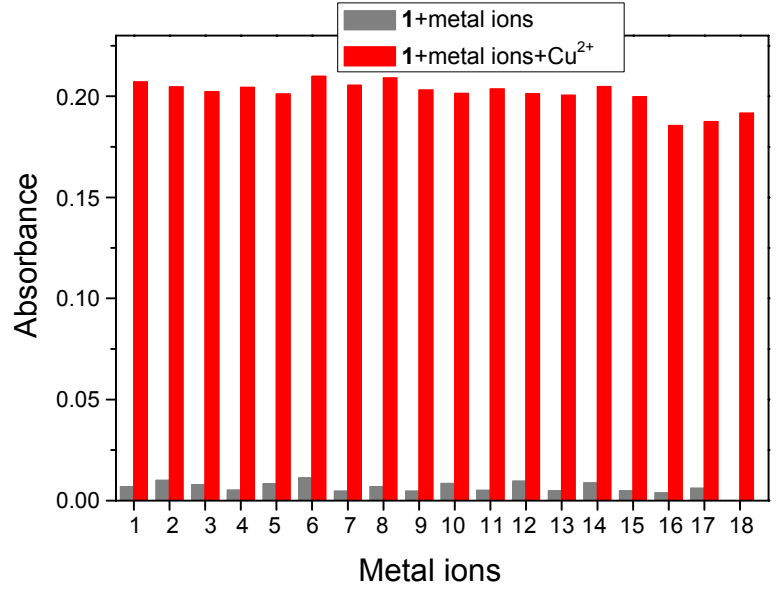

Figure 6. The absorbance of $1\left(1.0 \times 10^{-5} \mathrm{M}\right)$ at $557 \mathrm{~nm}$ to various metal ions. The grey bars represent the absorption of $\mathbf{1}$ in the presence of 8.0 equiv of miscellaneous metal ions, the red bars represent the absorption of the above solution upon addition of 8.0 equiv of $\mathrm{Cu}^{2+} .1 . \mathrm{Ni}^{2+}, 2$. $\mathrm{Hg}^{2+}, 3 . \mathrm{Ba}^{2+}, 4 . \mathrm{Ag}^{+}, 5 . \mathrm{Mg}^{2+}, 6 . \mathrm{Fe}^{2+}, 7 . \mathrm{K}^{+}, 8 . \mathrm{Ce}^{3+}, 9 . \mathrm{Mn}^{2+}, 10 . \mathrm{Pb}^{2+}$, 11. $\mathrm{Na}^{+}, 12 . \mathrm{Sr}^{2+}, 13 . \mathrm{Co}^{2+}, 14 . \mathrm{Zn}^{2+}, 15 . \mathrm{Cd}^{2+}, 16 . \mathrm{Cr}^{3+}, 17 . \mathrm{Fe}^{3+}, 18 . \mathrm{Cu}^{2+}$.

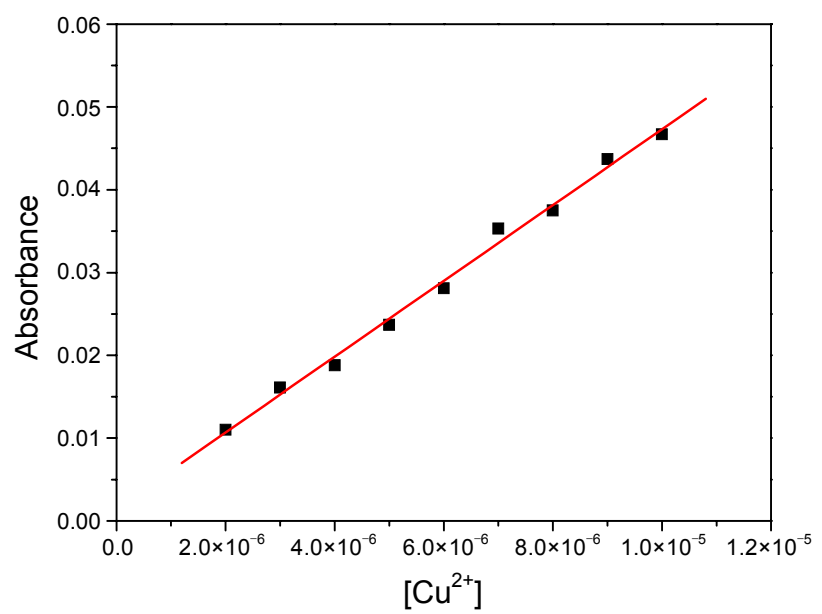

Figure 7. Absorption intensity of solution 1 versus the concentration of $\mathrm{Cu}^{2+}$ in the low concentration range $\left(2.0 \times 10^{-6}\right.$ to $\left.1.0 \times 10^{-5} \mathrm{M}\right)$.

In addition, to check its practical utility, the colorimetric detection limit of $\mathbf{1}$ for $\mathrm{Cu}^{2+}$ was evaluated. Under the present conditions, a good linear relationship between the absorption intensity and the $\mathrm{Cu}^{2+}$ concentration could be obtained in the $2.0 \times 10^{-6}$ to $1.0 \times 10^{-5} \mathrm{M}$ range $(\mathrm{R}=0.9969)$ (Fig. 7). The detection limit is then calculated to be $2.8 \times 10^{-7} \mathrm{M}$ with the equation: detection limit $=3 S / \rho,{ }^{11}$ where $S$ is the standard deviation of blank measurements, $\rho$ is the slope between intensity versus sample concentration. This result indicates that our colorimetric $\mathrm{Cu}^{2+}$ probe $\mathbf{1}$ is sensitive enough to monitor $\mathrm{Cu}^{2+}$ concentration in water.

Furthermore, the effect of $\mathrm{pH}$ on the absorbance of $\mathbf{1}$ in $\mathrm{CH}_{3} \mathrm{CN}$-water (2:3, v/v, $10 \mathrm{mM}$ HEPES, $\left.\mathrm{pH}=7.0\right)$ was determined. The acid-base titration experiments showed that sensor 1 has a very weak absorption at $\mathrm{pH} 6$ and has no absorption at $\mathrm{pH}$ greater than 7 (Fig. 8). This result revealed that $\mathbf{1}$ is suitable for detection of $\mathrm{Cu}^{2+}$ at near neutral $\mathrm{pH}$ conditions. 


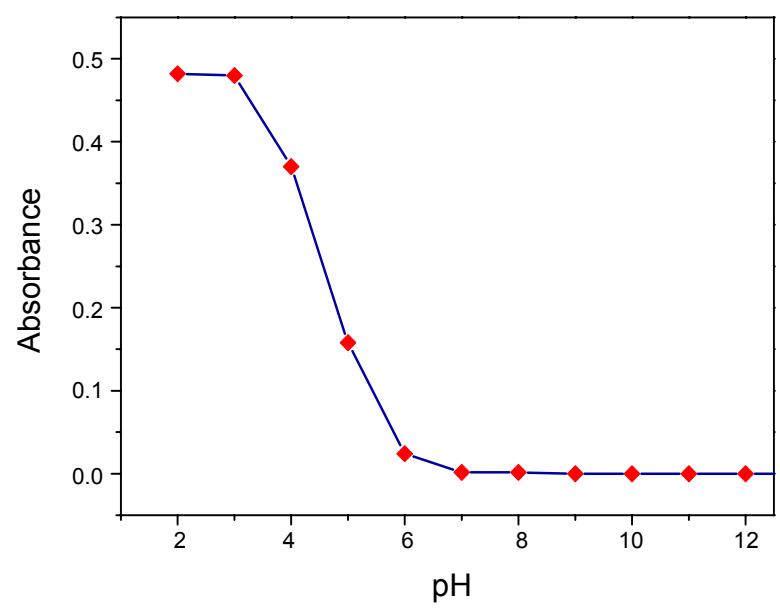

Figure 8. The effect of $\mathrm{pH}$ on the absorption $(557 \mathrm{~nm})$ of $\mathbf{1}\left(1.0 \times 10^{-5}\right.$ $\mathrm{M})$ in $\mathrm{CH}_{3} \mathrm{CN}$-water $(2: 3, \mathrm{v} / \mathrm{v}$, HEPES $10 \mathrm{mM}, \mathrm{pH}=7.0)$, the $\mathrm{pH}$ was modified by adding $75 \% \mathrm{HClO}_{4}$ or $\mathrm{NaOH}(10 \%, 30 \%)$.

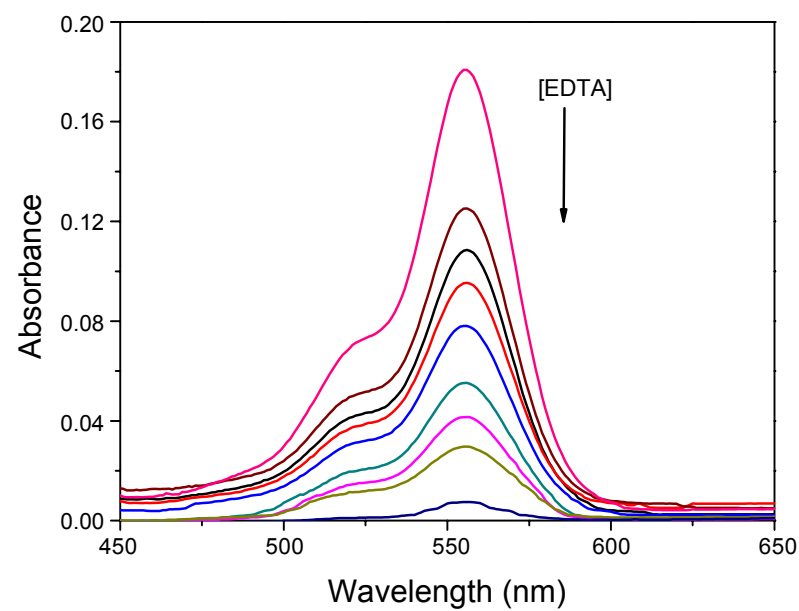

Figure 9. Changes in absorption spectra of 1 upon addition of EDTA$\mathrm{Na}_{2}$ in $\mathrm{CH}_{3} \mathrm{CN}$-water $(2: 3, \mathrm{v} / \mathrm{v}, 10 \mathrm{mM}$ HEPES, $\mathrm{pH}=7.0)$ solution.

Subsequently, we examined the chemical reversibility behavior of the binding of $\mathbf{1}$ and $\mathrm{Cu}^{2+}$ in the $\mathrm{CH}_{3} \mathrm{CN}$-water buffer solution (Fig. 9). Ethylene diamine tetraacetic acid disodium salt $\left(\mathrm{EDTANa}_{2}\right)$ was selected as the titration reagent due to its high affinity to $\mathrm{Cu}^{2+}$. Accordingly, a HEPES buffered solution $(\mathrm{pH}=7.0)$ composed of $1\left(1.0 \times 10^{-5} \mathrm{M}\right)$ and $\mathrm{Cu}^{2+}\left(8.0 \times 10^{-5} \mathrm{M}\right)$ was titrated with EDTANa 2 . As expected, addition of EDTANa led to a significant absorption decrease at $557 \mathrm{~nm}$ and the solution turned into its original colorless state when excess ED$\mathrm{TANa}_{2}$ was added, this result revealed the response of $\mathbf{1}$ to $\mathrm{Cu}^{2+}$ is reversible rather than a cation catalyzed reaction.

After coordination to $\mathrm{Cu}^{2+}$, sensor 1 only exhibited the characteristic color change, and did not generate the strong fluorescence emission of rhodamine type. This can be attributed to the quenching effect by paramagnetic $\mathrm{Cu}^{2+}$. Similar phenomena was also observed in other experiments. ${ }^{12}$

The plausible binding mode of $\mathbf{1}$ with $\mathrm{Cu}^{2+}$ that led to the absorbance changes is proposed in Scheme 2. According to the proposed mechanism of some rhodamine-based chemo-
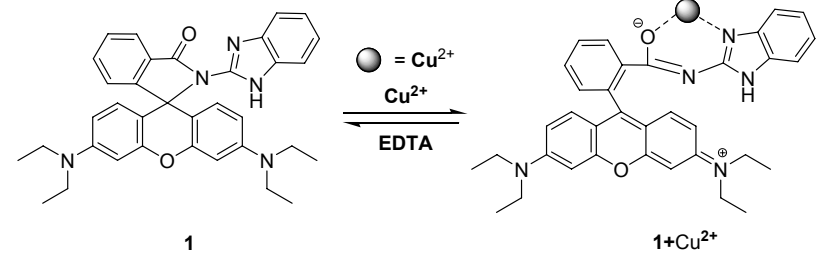

Scheme 2. Proposed binding mechanism between 1 and $\mathrm{Cu}^{2+}$.

sensors for metal ions, ${ }^{6,7,13}$ it can be supposed that the oxygen atom of the carbonyl group as well as a nitrogen atom on the benzimidazole moiety can cooperatively participate in the binding with $\mathrm{Cu}^{2+}$ and induce the ring-opening of the spirolactam.

\section{Conclusion}

In summary, we developed a new and simple rhodamine-based colorimetric chemosensor $\mathbf{1}$, which displays high selectivity and sensitivity toward $\mathrm{Cu}^{2+}$ and shows no significant response to other evaluated metal ions. The $\mathrm{Cu}^{2+}$ recognition process of $\mathbf{1}$ is not significantly influenced by other coexisting metal ions. The interaction of $\mathbf{1}$ and $\mathrm{Cu}^{2+}$ is proved to be reversible with a $1: 1$ binding stoichiometry, and the detection limit is found to be $2.8 \times 10^{-7} \mathrm{M}$.

Acknowledgments. This work was supported by the foundation of educational department of liaoning province (No: 2008T002).

\section{References}

1. (a) Sigel, H. Metal Ions in Biological Systems: Properties of Copper; Vol. 12, Marcel Dekker: New York, 1981. (b) Waggoner, D. J.; Bartnikas, T. B.; Gitlin, J. D. Neurobiol. Dis. 1999, 6, 221-230. (c) Barceloux, D. G. J. Toxicol. Clin. Toxicol. 1999, 37, 217-230. 2. (a) Hamza, I.; Gitlin, J. D. J. Bioenerg. Biomembr. 2002, 34, 381388. (b) López-Serrano, D.; Solano1, F.; Sanchez-Amat, A. Microbiology 2007, 153, 2241-2249.

3. (a) Brown, D. R.; Kozlowski, H. Dalton Trans. 2004, 1907-1917. (b) Leach, S. P.; Salman, M. D.; Hamar, D. Anim. Health Res. Rev. 2006, 7, 97-105. (c) Barnham, K. J.; Bush, A. I. Curr. Opin. Chem. Biol. 2008, 12, 222-228. (d) Crichton, R. R.; Dexter, D. T.; Ward, R. J. Coord. Chem. Rev. 2008, 252, 1189-1199. (e) Brewer, G. J. Cell Biol. Toxicol. 2008, 24, 423-470.

4. (a) Hahn, S. H.; Tanner, M. S.; Danke, D. M.; Gahl, W. A. Biochem. Mol. Med. 1995, 54, 142-145. (b) Zietz, B. P.; de Vergara, J. D.; Dunkelberg, H. Environ. Res. 2003, 92, 129-138.

5. (a) Kaur, N.; Kumar, S. Dalton Trans. 2006, 3766-3771. (b) Morgade, M.; Planells, M.; Torres, T.; Ballester, P.; Palomares, E. J. Mater. Chem. 2008, 18, 176-181. (c) Basurto, S.; Riant, O.; Moreno, D.; Rojo, J.; Torroba, T. J. Org. Chem. 2007, 72, 4673-4688. (d) Sheng, R.; Wang, P.; Gao, Y.; Wu, Y.; Liu, W.; Ma, J.; Li, H.; Wu, S. Org. Lett. 2008, 10, 5015-5018. (e) Huang, J.; Xu, Y.; Qian, X. Dalton Trans. 2009, 1761-1766. (f) Xu, Z.; Qian, X.; Cui, J. Org. Lett. 2005, 7, 3029-3032. (g) Xu, Z.; Pan, J.; Spring, D. R.; Cui, J.; Yoon, J. Tetrahedron 2010, 66, 1678-1683. (h) Gunnlaugsson, T.; Leonard, J. P.; Murray, N. S. Org. Lett. 2004, 6, 1557-1560. (i) Choi, S. H.; Pang, K.; Kim, K.; Churchill, D. G. Inorg. Chem. 2007, 46, 10564-10577. (j) Huang, J.; Xu, Y.; Qian, X. Org. Biomol. Chem. 2009, 7, 1299-1303. (k) Kaur, N.; Kumar, S. Chem. Com- 
mun. 2007, 3069-3070.

6. (a) Jun, M. E.; Ahn, K. H. Org. Lett. 2010, 12, 2790-2793. (b) Egorova, O. A.; Seo, H.; Chatterjee, A.; Ahn, K. H. Org. Lett. 2010, 12, 401-403. (c) Chatterjee, A.; Santra, M.; Won, N.; Kim, S.; Kim, J. K.; Kim, S. B.; Ahn, K. H. J. Am. Chem. Soc. 2009, 131, 20402041. (d) Kwon, J. Y.; Jang, Y. J.; Lee, Y. J.; Kim, K. M.; Seo, M. S.; Nam, W.; Yoon, J. J. Am. Chem. Soc. 2005, 127, 10107-10111. (e) Ko, S.-K.; Yang, Y.-K.; Tae, J.; Shin, I. J. Am. Chem. Soc. 2006, 128, 14150-14155. (f) Xiang, Y.; Tong, A. Org. Lett. 2006, 8, 15491552. (g) Zheng, H.; Qian, Z.; Xu, L.; Yuan, F.; Lan, L.; Xu, J. Org. Lett. 2006, 8, 859-861. (h) Xiang, Y.; Tong, A.-J.; Jin, P.-Y.; Ju, Y. Org. Lett. 2006, 8, 2863-2866. (i) Zhang, M.; Gao, Y.; Li, M.; Yu, M.; Li, F.; Li, L.; Zhu, M.; Zhang, J.; Yi, T.; Huang, C. Tetrahedron Lett. 2007, 48, 3709-3712. (j) Kim, H. N.; Lee, M. H.; Kim, H. J.; Kim, J. S.; Yoon, J. Chem. Soc. Rev. 2008, 37, 1465-1472.

7. (a) Yang, Y.-K.; Yook, K.-J.; Tae, J. J. Am. Chem. Soc. 2005, 127, 16760-16761. (b) Zhao, M.; Yang, X.; He, S.; Wang, L. Sens.
Actuators B: Chem. 2009, 135, 625-631.

8. (a) Berends, H. P.; Stephan, D. W. Inorg. Chem. 1987, 26, 749-754. (b) Berends, H. P.; Stephan, D. W. Inorg. Chim. Acta 1985, 99, L53-L56.

9. Zhang, X.; Shiraishi, Y.; Hirai, T. Tetrahedron Lett. 2007, 48, 5455-5459.

10. Conner, K. A. Binding Constants-the Measurement of Molecular Complex Stability; Wiley: New York, 1987.

11. Sun, Y.; Liu, Y.; Guo, W. Sens. Actuators B: Chem. 2009, 143, 171-176.

12. (a) Tsuge, K.; DeRosa, F.; Lim, M. D.; Ford, P. C. J. Am. Chem. Soc. 2004, 126, 6564-6565. (b) Kim, M. H.; Noh, J. H.; Kim, S.; Ahn, S.; Chang, S. K. Dyes. Pigm. 2009, 82, 341-346.

13. (a) Zhang, L.; Fan, J.; Peng, X. Spectrochim. Acta. Part A 2009, 73, 398-402. (b) Huang, J.; Xu, Y.; Qian, X. J. Org. Chem. 2009, 74, 2167-2170. (c) Soh, J. H.; Swamy, K. M. K.; Kim, S. K.; Kim, S.; Lee, S. H.; Yoon, J. Tetrahedron Lett. 2007, 48, 5966-5969. 